\title{
Penerapan PECS-Bahan Ajar Autisme
}

\section{Romy Budhi Widodo*, Windra Swastika dan Kestrilia Rega Prilianti}

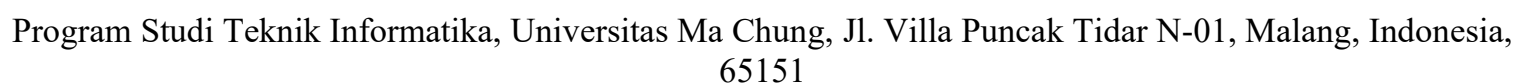

Correspondence: romy.budhi@machung.ac.id

Received: 30 Juni 2021 - Revised: 01 Agustus 2021 - Accepted: 16 Agustus 2021

\begin{abstract}
Abstrak. Kegiatan yang dilakukan bertujuan untuk memberikan nilai lebih kepada mitra. Pada kesempatan ini, kelompok kami berusaha ingin memberikan nilai lebih kepada salah satu Wisma Epilepsi yang ada di kota Malang. Di wisma tersebut terdapat anak autis, ASD (Autism Spectrum Disorder) dan sekaligus hiperaktif yang berusia 14 tahun. Dari hasil pengamatan oleh pembina, anak asuh dengan ASD ini memiliki tipe belajar visual. Alat-alat bermain dan belajar visual yang telah dimiliki perlu dianalisis dan jika perlu ditingkatkan keberagamannya sesuai kerjasama dengan penanggung jawab wisma. Keragaman bahan ajar juga disesuaikan dengan kemajuan pemahaman konsep dari anak tersebut. Beberapa alat belajar juga sering mengalami kerusakan sehingga diperlukan cara melindungi alat-alat belajar tersebut dari koyak dan kerusakan. Luaran sosial yang diharapkan adalah adanya peningkatan kemampuan dan kreatifitas anak ASD di Wisma Epilepsi tersebut. Pada kegiatan ini usaha menerapkan PECS-picture exchange communication system-dilakukan meski kendala pertemuan fisik yang jumlahnya tidak dapat terlalu banyak disebabkan ketidaknyamanan interaksi fisik di masa pandemi. Hasil pengamatan dari beberapa kali pertemuan dengan menerapkan PECS diperoleh bahwa penggabungan PECS dan model 3 dimensi, lebih sesuai digunakan, daripada hanya metode PECS saja, pada subjek.
\end{abstract}

Kata kunci: ASD, PECS, model 3D

Citation Format: Widodo, R.B., Swastika, W. \& Prilianti, K.R. (2021). Proposal Pengembangan Bahan Ajar Autisme di Wisma Epilepsi. Prosiding Seminar Nasional Abdimas Ma Chung (SENAM), 333-340. 


\section{PENDAHULUAN}

Wisma Epilepsi adalah suatu tempat yang digunakan untuk penyandang epilepsi, namun juga ditempati beberapa anak diantaranya tuna grahita, tuna daksa, ASD (Autism Spectrum Disorder), hiperaktif, dan tuna ganda. Wisma ini di bawah naungan yayasan sosial untuk anak difabel yang berada di Jawa, Kalimantan, Flores, Timor, Sumba, Tanimbar, dan Dilli. Di dalam wisma tersebut terdapat pengasuh bagi setiap anak dan koordinator wisma. Dari wawancara dengan koordinator wisma, anggota dari wisma tersebut adalah satu anak asuh tuna grahita, cakap dalam menjahit dasar; satu anak asuh, tuna daksa, dapat mengoperasikan komputer (mengetik); satu anak asuh, tuna ganda, hanya mampu rawat; dan satu anak asuh, autis (Autism Spectrum Disorder/ASD) dan hiperaktif, mampu latih (masih punya peluang untuk dilatih).

\section{MASALAH}

Sebelum masa pandemi, setiap pagi semua anak asuh akan diantar ke sekolah dan mengikuti pelajaran yang dibimbing oleh pengajar khusus. Pada masa pandemi ini seluruh kegiatan sekolah dilaksanakan secara daring di wisma masing-masing anak asuh. Namun, dengan segala keterbatasan perangkat, peralatan dan kemampuan fisik anak-anak yang ada di wisma epilepsi, pengajaran secara daring kurang efektif sehingga fokus pembelajaran anak asuh dilakukan di Wisma Epilepsi secara personal antara pelatih dan anak asuh.

Permasalahan pertama yang dirasakan di Wisma Epilepsi adalah inventaris belajar bagi salah satu anak asuh autis, sering mengalami kerusakan (sobek dan lusuh). Misalnya buku, poster, dan sarana belajar lainnya. Permasalahan kedua yang dirasakan adalah pemberdayaan anak asuh untuk kemandiriannya kelak. Belum adanya pemberdayaan yang berhubungan dengan ekonomi mandiri.

Berdasarkan hasil wawancara dengan pembimbing di wisma. Saat ini wisma epilepsi berpotensi untuk membuat usaha dengan pemberdayaan anak asuh yang memiliki keterampilan khusus seperti menjahit dan atau komputer. Demikian juga diperlukannya pembuatan perlindungan materi belajar bagi anak asuh autis supaya tidak mudah rusak.

Pada kesempatan ini, fokus kegiatan adalah mewujudkan inventaris belajar yang menyenangkan bagi anak autis. Inventaris belajar dibuat dengan landasan-landasan pembelajaran bagi anak autis. Teori-teori pembelajaran anak autis mengenai visualisasi dan labelisasi diharapkan akan mendasari pembuatan inventaris belajar bagi anak autis dan hiperaktif. Penerapan teknologi pembelajaran untuk anak autis diharapkan dapat 
meningkatkan cara berkomunikasi antara anak asuh dengan instruktur dan rekan-rekan anak asuh.

\section{METODE PELAKSANAAN}

Seperti diungkapkan dalam beberapa literatur bahwa anak autis adalah anak dengan perilaku yang berfokus pada dirinya sendiri. Sering melakukan pengulangan tingkah laku, berbicara dengan topik monoton, dan ciri-ciri lain (Ivony, 2016; Pamuji, 2014). Pencetus istilah autis adalah Leo Kanner, dokter kesehatan jiwa anak, pada tahun 1943. Autisme sendiri adalah gangguan neurologis, yang menyebabkan anak hidup dalam dunianya sendiri. Gangguan neurologis ini berakibat pada gangguan spektrum. Anak autis memiliki gejala dan intensitas yang beragam. Ada anak yang tidak dapat berbicara sama sekali hingga ke bentuk bicara yang isinya monoton. Gangguan neurologis berakibat pada gangguan fungsi otak yang ditandai dengan:

- Kesulitan kemampuan interaksi sosial dan komunikasi.

- Gerakan tubuh yang berulang-ulang atau pola perilaku tertentu.

- Kesulitan akademis.

Kriteria untuk menentukan anak autis adalah diagnosis klinis DSM-IV (Diagnostic and Statistic Manual-IV) dari kelompok psikiater Amerika di tahun 1994. Adapula instrumen lain yaitu sistem penilaian Childhood Autism Rating (CARS rating system), Checklist for Autism in Toddlers (CHAT), dan Autism Screening Questionnaire (Griadhi, Made Ovy Riandewi Ratep \& Westa, 2013).

Beberapa pola belajar anak autis (Pamuji, 2014), yaitu:

a. Rote learner, tipe penghafal tanpa memahami makna simbol.

b. Gestalt learner, cenderung melihat secara keseluruhan. Misalnya menghafal kalimat tanpa memahami arti per katanya.

c. Visual learner, tipe pembelajar dari apa yang dilihat. Misalnya mempelajari komunikasi dengan simbol dan gambar.

d. Hands on learner, anak tipe ini dapat mempelajari sesuatu dari apa yang dicobanya.

e. Auditory learner, tipe senang berbicara dan lebih mudah memahami sesuatu dari apa yang didengar.

Dari pengalaman koordinator wisma, melihat bahwa anak asuh ASD adalah type visual learner. Solusi yang ditawarkan bersama-sama dengan koordinator adalah: 
- Perbaikan bahan ajar/inventaris belajar yang sudah ada, misalnya perbaikan cover, warna, bentuk, dan fisik lainnya.

- Penambahan inventaris belajar sesuai kurikulum belajar ASD dan kemampuan/keadaan anak asuh.

Sebab anak asuh adalah tipe visual learner, metode PECS (picture exchange communication system) dan kombinasinya dengan model permainan tiga dimensi menjadi pilihan dalam kegiatan ini.

\section{HASIL DAN PEMBAHASAN}

Tujuan PECS (picture exchange communication system) supaya anak memiliki keinginan (inisiasi) untuk berkomunikasi dengan mengambil gambar yang sesuai dari bukunya masing-masing. PECS mengajarkan lebih kepada "apa yang anak mau" daripada “apa yang instruktur mau”; PECS membuat anak menjadi better learner (pebelajar yang lebih baik). Gambar 1 adalah contoh dari PECS.

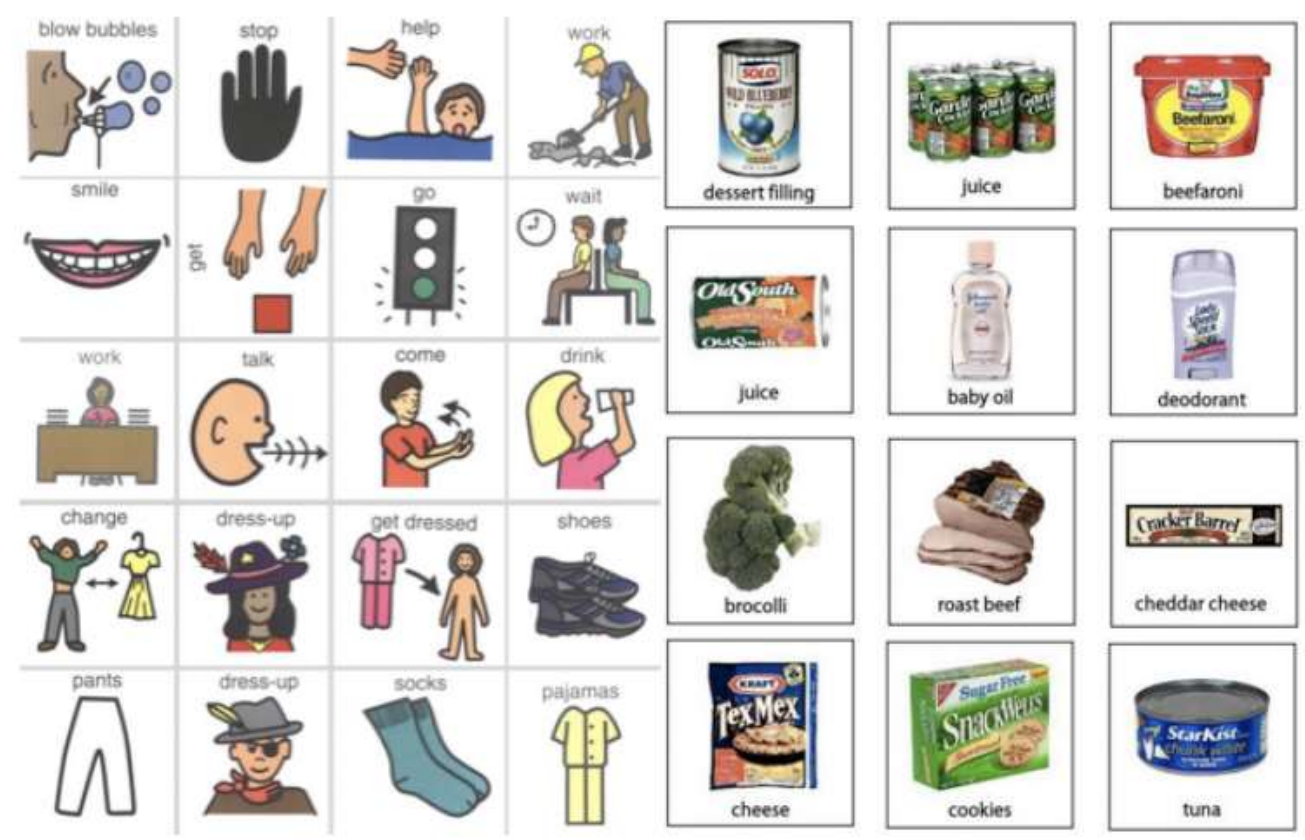

Gambar 1. Contoh dari PECS yang digunakan untuk media pembelajaran ASD (da Silva, 2013).

Langkah awal adalah mengenali apa yang disukai oleh anak, misal: makanan, minuman, mainan dan sebagainya. Anak dengan ASD di wisma menyukai permen Yupi dan kue bulat merek Tricks. Permen Yupi dan kue digunakan sebagai penguatan (reinforcement) atau sebagai hadiah atas keberhasilan anak dalam mengerjakan tugas yang 
diberikan instruktur. Dari sumber referensi (Barnes et al., 2011) dan (https://www.youtube.com/watch?v=rsDBJyrcyh0\&t=971s) diperoleh PECS memiliki enam langkah sebagai berikut:

\section{PHASE I: The physical exchange}

Phase ini bertujuan supaya anak tahu arti menukar. Tekniknya: ada kartu sembarang dan ada hadiah. Jika anak mau menukar kartunya maka dia akan diberi hadiah sebagai reinforcement. Ada dua instruktur: Satu instruktur sebagai partner komunikasi (communicative partner) yang sekaligus memberi hadiah, satu instruktur lain sebagai asisten fisik (physical promter) anak tersebut, misal membantu memegang tangan anak tersebut. Instruktur dapat bertukar peran, supaya anak memahami komunikasi dengan banyak orang. Semua kegiatan phase I, harus dihentikan sebelum anak jenuh dan marah.

\section{PHASE II: Expanding spontaneity/travel}

Phase ini mulai ada jarak fisik antara dua instruktur dan anak. Anak diberi barang kesukaannya jika sudah memberi kartu. Gambar kartu disesuaikan dengan bentuk barang yang mau diambil oleh anak. Jika anak menjauh maka tugas pengasuh membantu secara fisik. Anak diminta sudah bisa berjalan ke instruktur dan menarik perhatian instruktur sebelum memberikan pertukaran benda.

\section{PHASE III: Discrimination training}

Tujuan phase ini: anak dapat memilih gambar yang benar sesuai arti yang benar (The right picture for the right mean). Di sini anak diajarkan dapat memisahkan mana benda A, mana benda B. Anak disuguhi dua benda yang mana ia suka dan tidak suka. Anak akan mengambil gambar binatang harimau dan meminta miniatur harimau, instruktur memberikan benda yang sesuai dengan gambar yang diberikan.

\section{PHASE IV: Sentence structure}

Tujuan: Melatih anak menggunakan kalimat sederhana.

\section{PHASE V: Responding to "What do you want?"}

Tujuan: Setelah memahami membentuk kalimat, anak diajari menjawab pertanyaan sederhana: "Kamu ingin apa?"

PHASE VI: Responsive and spontaneous commenting 
Tujuan: Dalam komunikasi, selain request (meminta) diperlukan juga comment (kemampuan memberi komentar). Harapannya, anak dapat membedakan antara dua gambar, yaitu "Saya melihat ..." dan "Saya ingin..."

Kegiatan telah dilaksanakan dengan jumlah kunjungan empat kali ke wisma dalam rangka mendiskusikan bahan ajar. Dalam kunjungan tersebut pertemuan dengan anak autisme hanya sebentar-sebentar disebabkan keadaan fisik, pandemik, dan waktu istirahat anak. Secara umum bahan ajar menggunakan model kartu dan pengenalan bentuk fisik. Bahan ajar dibuat dan sebagian diperoleh dengan membeli. Pada awalnya akan diterapkan metode PECS, akhirnya dikembangkan juga dengan model tiga dimensi sebagai alat peraga. Tahapan PECS yang dilakukan adalah phase I, II, dan III. Gambar 1 mengilustrasikan bahan ajar yang digunakan, yang merupakan gabungan bahan ajar 2 dimensi dan 3 dimensi. Penggunaan flash card bergambar seperti pada Gambar 1b, digunakan untuk kegiatan sehari-hari, misalnya gambar nasi identik dengan meminta makan dan gambar gelas identik dengan meminta minum seperti disarankan dalam (Amonev, n.d.).

Dalam pelaksanaannya teknik flash card memerlukan gambar yang mengilustrasikan kebiasaan sehari-hari. Gambar nasi dan gelas yang menunjukkan permintaan makan dan minum perlu diganti sebab untuk kegiatan makan sudah memiliki jadwal tersendiri. Demikian juga minum sudah memiliki tempat sendiri dan mudah dijangkau anak asuh.

Bentuk kegiatan lainnya hingga kunjungan terakhir, digunakan flash card gambar binatang untuk membantu anak asuh mengenali bentuk binatang 3D. Jenis pelatihan ini adalah discrimination training, dimana anak asuh bisa menukar kartu maupun memasangkan kartu dengan model animal 3D yang sesuai. Reinforcement diberikan berupa kudapan kue dan permen jika anak berhasil mengenali bentuk binatang, seperti pada Gambar 1a.

Kegiatan lain adalah bermain puzzle seperti pada Gambar 1d. Puzzle tiga dimensi sangat disukai anak asuh. Kecepatannya merangkai puzzle dan ketepatannya dalam meletakkan potongan puzzle mengagumkan.

Kegiatan ini dilaksanakan dalam masa pandemi, berbagai kesulitan dan kekawatiran dalam pelaksanaan program sangat dirasakan. Meski dirasakan jumlah pertemuan belum maksimal, namun inisiasi bahan ajar telah dilakukan, repetisi perlu dilakukan kepada anak asuh. Di tengah kesibukan koordinator wisma, kami 
mengharapkan repetisi metode PECS dilakukan oleh pelatih di wisma supaya anak asuh dapat menggunakan kartu untuk media komunikasi.

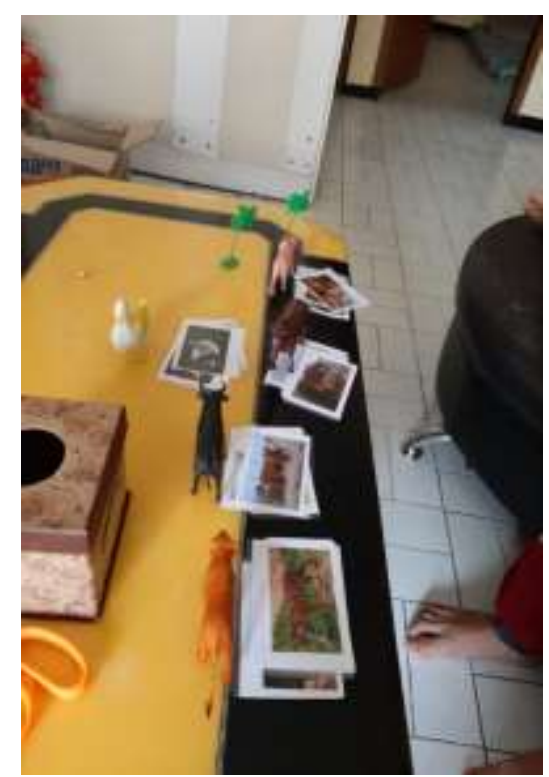

(a)

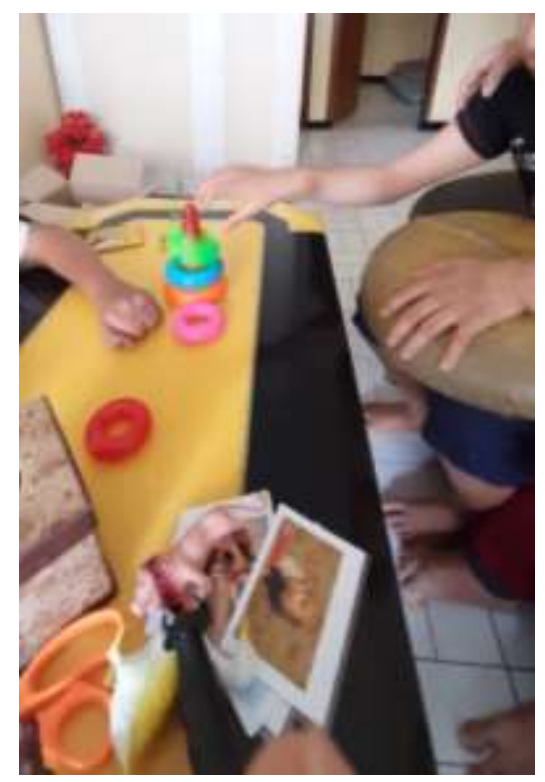

(c)

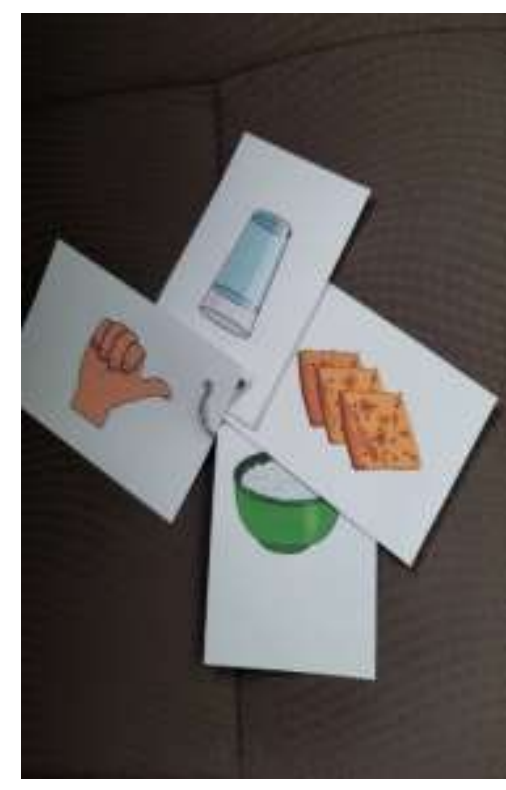

(b)

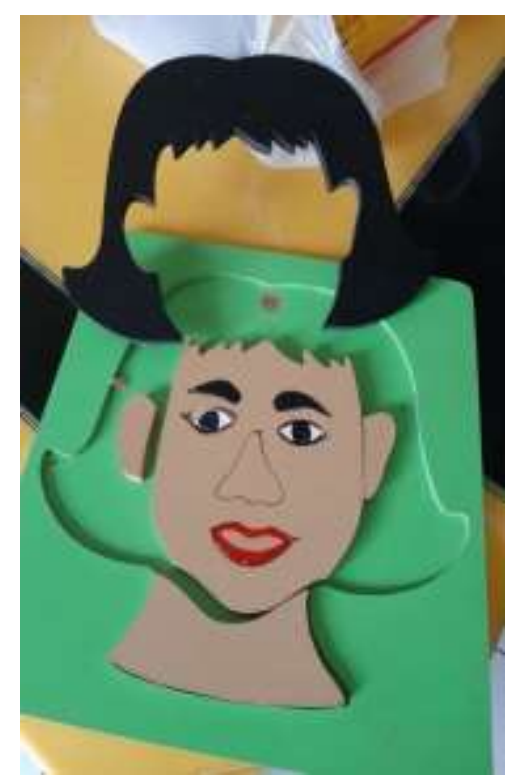

(d)

Gambar 2. a) Bahan ajar dua dimensi dan tiga dimensi, model binatang untuk PECS tahap III; b) Flash card bergambar kebutuhan dasar (makan, minum, kudapan) dan konfirmasi (gambar ibu jari); c) Permainan menyusun bentuk, dengan bantuan asisten fisik; d) Puzzle wajah (inventaris wisma) 


\section{KESIMPULAN}

Penggabungan PECS, model 3 dimensi, dan puzzle sangat menarik dalam bermain bersama anak asuh ASD. Keberadaan reinforcement berupa hadiah kepada anak asuh jika berhasil menjalankan tugas, diamati telah memberikan penguatan yang positif. Kegiatan lanjutan perlu dilakukan oleh pelatih di wisma dalam rangka repetisi PECS langkah I, II, dan III.

\section{UCAPAN TERIMA KASIH}

Ucapan terima kasih ditujukan kepada penanggung jawab wisma epilepsi, Bruder Olla, yang telah mendampingi dan memberikan perhatian kepada kelompok dan pengabdiannya kepada anak-anak asuh.

\section{DAFTAR PUSTAKA}

Amonev. (n.d.). Speech Delay Non Verbal Children and adults with Autism or Special Needs My Essential Needs Cards 12 Flash Cards for visual aid Special Ed. International Journal for Innovative Research in Science \& Technology. http://ijirst.org/Flash-Cards/933899-visual-aid-Special-Ed-Speech-Delay-Non-VerbalChildren-and-adults/

Barnes, C. S., Dunning, J. L., \& Rehfeldt, R. A. (2011). An evaluation of strategies for training staff to implement the picture exchange communication system. Research in Autism Spectrum Disorders, 5(4), 1574-1583. https://doi.org/10.1016/j.rasd.2011.03.003

da Silva, M. A. R. L. (2013). Improving the Outcomes of Children with Autism Spectrum Disorders through User-tuned Content Customization (Doctoral dissertation, Master's thesis, Instituto Superior Técnico).

Griadhi, Made Ovy Riandewi Ratep, N., \& Westa, W. (2013). Diagnostic and Management of Autism. Medika Udayana, 2(11), 1-14. https://ojs.unud.ac.id/index.php/eum/article/view/7026

Ivony, T. (2016). Strategi Pembelajaran Anak Autis di SLB Autisma Yogasmara, Semarang. In Pendidikan Non Formal, FIP, Universitas Negeri Semarang.

Pamuji. (2014). Adaptasi Media Pembelajaran Gambar. Ortopedagogia, VOLUME 1, 117127. http://journal.um.ac.id/index.php/jo/article/download/8250/3786 